\title{
Development of Technopolitan Region in Pelalawan Regency of Riau Province in Collaborative Governance Perspective
}

\author{
Ranggi Ade Febrian \\ Department of Government Science \\ Islamic University of Riau \\ Pekanbaru, Indonesia \\ Ranggifebrian14@gmail.com \\ Utang Suwaryo \\ Padjadjaran University \\ Bandung, Indonesia
}

Student of Doctoral Program at Padjadjaran University

\author{
Dede Sri Kartini \\ Padjadjaran University \\ Bandung, Indonesia
}

\author{
Priyo Teguh \\ Institute of Government in the state(IPDN) \\ Bandung, Indonesia
}

\begin{abstract}
Judging from the national policy of the Masterplan of Acceleration and Expansion of Indonesian Economic Development (MP3EI) 2011-2025, especially the development of Sumatra Island Economic Corridor, that the development of Technopolitan Region in Pelalawan Regency, Riau Province starting from 2012 is one of strategic effort to develop potency-based region natural resources by relying on technology to enhance added value and integrated collaboration between government, research and development institutions, industry and society. Collabarative Governance as a new variant in the concept of governance becomes a new perspective as a formula in viewing the development of technopolitan area in Pelalawan Regency which has not finished its development until 2017. Using the theory of collaborative governance by Stephan Balogh (2011) consists of three dimensions: system context, drivers, and collaborative dynamics as an analytical tool, indicating resource imbalances in the system context dimension, high commitment of heads of regional leadership in the dimensions of drivers, and social capital Underutilized in the dimensions of collaborative dynamics.
\end{abstract}

Keywords: Technopolitan, Collaborative, and Governance

\section{INTRODUCTION}

In the era of regional autonomy and globalization, each region seeks to increase its capacity and productivity so as to have high competitiveness. With the increased competitiveness, will have an impact on improving people's welfare. Each region is unique because each region has the ability to create and develop and offer the most productive climate / environment for business and innovation, attraction or attract investment, talented people, and other mobile factors, and the potential for sustained superior performance. Even the future of each region or jointly develop the climate/environment, social, culture, and have a good opportunity to grow according to the talents and creativity of innovation.

Pelalawan Regency is one of the regencies in Riau Province, has abundant natural resources, especially in the plantation sector, especially the main commodities of palm oil, rubber and coconut. In addition, there are also several large industries operating in Pelalawan District. This is a potential for developing a technopolitan area in Pelalawan District.

Judging from the national policy of the Master Plan for the Acceleration and Expansion of Indonesian Economic Development (MP3EI) 2011-2025, in particular the development of the Sumatra Island Economic Corridor, the development of Teknopolitan in Pelalawan District based on the downstream palm oil industry is one of the strategic efforts to develop resource-based region nature by relying on technology to enhance added value and integrated collaboration between government, research and development institutions, industry and society.

Development of Technopolitan Areas Pelalawan has the objective of creating a conducive environment for collaboration among academic, business, government (ABG) communities in order to improve the competitiveness of innovation-based and knowledge-based regions (konwledge based economy). Therefore, the urgency of this research is seen as an academic effort that tries to explore how the Collaborative Governance concept is able to analyze and provide solutions to the development of technopolitan areas in Pelalawan District. Because since it started in 2013 until now has not been able to develop, due to the constraints of limited development finance resources, in the midst of the many demands on the fulfillment of the need for development that must be achieved within the five years set forth in the RPJMD, then in need of selection and prioritization of development in Pelalawan District. Based on the concept of thought and the 
above phenomenon, the authors make a study with the title Development of Technopolitan Region In Pelalawan Regency of Riau Province In Collaborative Governance Perspective.

Departing from the phenomenon and the concept used then the formulation of the problem in this research is how the development of technopolitan region in Pelalawan Regency seen from the perspective of collaborative governance? While the purpose of research to explore how the development of technopolitan region in Pelalawan District, Riau Province.

\section{COLLABORATIVE GOVERNANCE}

The government does not only rely on the internal capacity it has in implementing a policy and implementing the program. The limited ability, resources and networks that support the implementation of a program or policy, encourage the government to cooperate with various parties, both with the government, private parties and community and civil society community so collaboration can be established in achieving the program or policy objectives. (Purwanti, 2016)

In general it is explained that Collaborative Governance is a process in which involved various relevant stakeholders to carry the interests of each agency in achieving common goals. (Cordery, 2004; Hartman et al., 2002). [1]

According to Ansell and Gash (2007) [2] defining Collaborative Governance is an arrangement that governs one or more public institutions directly involved with non-public stakeholders in a collective decision-making process that is formal, consensus-oriented, and deliberative aimed at making or implementing public policy or managing programs or public assets. The definition can be formulated several keywords that emphasize the six characteristics, namely:

First, the forum is initiated or implemented by public institutions and actors in public institutions. Second, participants in the forum also include non-public actors. Third, participants are directly involved in decision making and decision making and should not refer to public actors. Fourth, the forums are organized formally and meetings are held together. Fifth, the forum aims to make decisions on mutual agreement, in other words this forum is consensus-oriented. And sixth, collaboration focuses on public policy as well as public management.

This definition can be interpreted that the forum exists in a formal relation so that it is mentioned only in the range of cooperation between public institutions, public actors and nonpublic actors. Unlike the Collaborative Governance definition described by Agrawal and Lemos (2007) [3] explains the definition of Collaborative Governance not only limited to government and non-government stakeholders but also formed of multiparnert governance covering private sector, community and community civil and built on the synergy of the stakeholder role and the development of hybrid plans such as public-private and private-social cooperation. [4]
Similarly, Balogh (2011) concludes that Collaborative Governance is a process and structure in the management and formulation of public policy decisions involving actors constructively coming from various levels, both at the level of government and / or public institutions, private institutions and society civil society in order to achieve public goals that can not be achieved if implemented by one party only. [5]

Robertson and Choi (2010) (in Kumorotomo, 2013) define Collaborative Governance as a collective and egalitarian process whereby every participant in it has substantial authority in decision making and every stakeholder has equal opportunity to reflect on his aspirations in the process. [6]

Dwiyanto explains in detail that in collaborative collaboration the delivery of vision, goals, strategies and activities between the parties, they respectively but have the authority to make decisions independently and have authority in managing the organization even though they are subject to mutual agreement. (Dwiyanto, 2011) [7]

In line with Dwiyanto's definition, Sink describes collaborative collaboration as a process whereby organizations that have an interest in a particular problem seek to find a commonly defined solution in order to achieve goals that they do not achieve individually.

Collaborative Governance is based on the objective to solve together the issues or specific issues of the parties concerned. The party not only limited to government and non-government agencies, because in the principle of good governance, involving civil society in the formulation and decision-making. Cooperation is initiated on the limitations of capacity, resources and networks owned by each party, so that cooperation can unify and complement the various components that drive the success of achieving common goals. In the formulation of objectives, vision, mission, norms and values together in cooperation, the position of each party is equivalent to have the authority to make decisions independently, although bound by mutual agreement. (Purwanti, 2016: 178).

The dimension of collaborative governance used to explore the development of technopolitan areas in Pelalawan District uses the concept of Stephan Balogh (2011), which explains Collaborative Governance has three dimensions, namely system context, drivers, and collaboration dynamics. The dimensions are illustrated as follows:

Figure 1. Collaborative Governance Process Used in a Technopolitan Area Development Policy System.

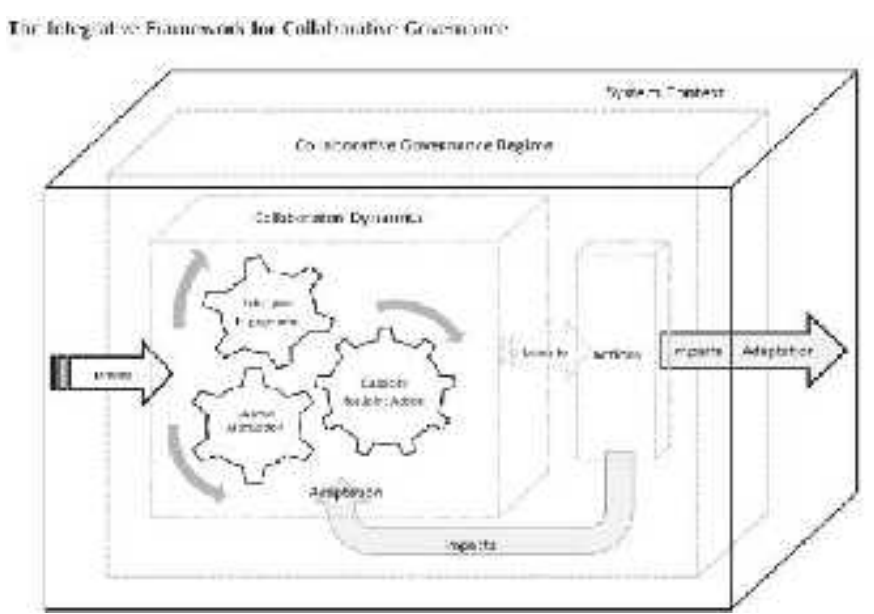


The three dimensions have elements that influence, namely the first dimension is described with the outermost box which is the scope / system contexs that shelters consists of seven elements, namely: Resouce Condition, Policy and Legal Framework, Level of Conflict /Trust, Socio-economic, health culture and variety (Condition Portrait), Prior failure to Address Issues, Political dynamics / power relations and Network connectedness.

The second dimension is the drivers consisting of collaboration dynamics and collaborative action, has 4 components of leadership and Consequential incentives, Interdependence, and Uncertainty. While the third dimension is a collaboration dynamic consisting of three components, namely: Principled Engagement, Shared Motivation, Capacity for Join action. This dimension is used because it is judged in accordance with the field phenomenon which emphasizes the partnership of every element involved in the development of teknolopolitan area.

\section{RESEARCH METHODS}

The approach used in this research is qualitative with explorative research type. This is considering that this study is more checking the phenomenon or the new little known, so it is expected to find the purpose of research in question so that it can develop in detail the concepts, models, or propositions in the research. Besides, the purpose of this qualitative research is to produce findings that can not be achieved (obtained) by using statistical procedures or by other means of quantification.

This research describes as a process of inquiry to understand human problems or problems, based on the creation of a complete holistic picture formed in words, reporting the informant's views in detail, and arranged in a natural setting. [8]

\section{IV.CRITICAL DISCUSSION}

\section{A) System Context}

The context system in developing teknopolitan area in Pelalawan district of Riau Province is determined by the condition of available policy and resources. For example, the development of Teknopolitan Pelalawan Regency requires policy support in accordance with Riau Province Development Policy. Harmonious and aligned policies between Riau Province and Pelalawan Regency became one of the main factors for the successful development of Teknopolitan in Pelalawan District. The support of a conducive policy from the Government of Riau Province will increase the investment attractiveness in the Technopolitan Region. The support of Riau Province's development policy towards the development of Teknopolitan Pelalawan will be reflected in the Long Term
Development Plan and the Medium Term Development Plan (RPJP / RPJM) of Riau Province.

In Pelalawan District the priority of development and the focus of the leading target of development has constraints due to limited financial resources of development, amidst the demands of fulfilling the need for development that must be achieved within five years. As reflected in the vision, mission, objectives and targets of the RPJMD 2011-2016, it is necessary to select and prioritize development and the focus of the key development goals calculated can be achieved in the final year of the regional leadership

Unfortunately the development of technopolitan areas does not become the priority scale of development in RPJMD 20112016, because Pelalawan Regency Government prefer Bono tourism development as the pre-eminent target. The indicator of achievement of the superior target of development of Pelalawan Regency in 2011 - 2016 is to realize eco-tourism based on community-based bono as well as environmental insight into the 20th national tourist destination and world tour destinations to the order of 200. This is of course greatly affect the development of technopolitan areas to be hampered in $2011-2016$ because sytem contexs that are influenced by policy and resource elements are prioritized on other superior goals.

It is not easy to realize that big dream. Many obstacles must be passed, for example in terms of budget. Certainly Pelalawan budget will not bear to sustain it. The Tecknopolitan megaproject is estimated to cost around $\mathrm{Rp} 47$ trillion. A very large amount when compared with only around $\mathrm{Rp} 1.5$ trillion per year.

In this phase, the main activity required is to prepare the legalization of the formation of technopolitan strategic areas of Pelalawan, consolidation of programs and activities, and consolidation of resources in the next period of 2017-2022. Therefore, the main activities are coordination, integration, and synergy with all related parties.

With the compilation of the concept of development of technopolitan Pelalawan area in the period 2017-2022, the next step is to arrange indications of programs and development activities of Pelalawan technopolitan area. Indications of the program and activities are set to optimize the preparation of technical programs and efforts to encourage the participation of all parties, whether government, private, or public. Then there is also the preparation of integration between stakeholders because in the process of developing the area involves many agencies / institutions concerned. So that will be realized sharing of activities and resources within the framework of collaborative governance to run a consensus with the established.

\section{B) Drivers}

Leadership becomes a very prominent element in the development of technolopolitan region based on collaboration seen from the dimensions of drivers. The role of regional heads to mobilize other actors such as the private sector, 
society, universities and central government is absolutely necessary.

Because the Strategic Area of Teknopolitan Pelalawan is targeted to be able to realize the relationship between higher education institution, research and development institution, and industry which is a vehicle for strengthening innovation network and become the innovation agent of the region, so that the condition can be realized, support and commitment of Regional Leaders become very important especially in:

- To appoint the management of Teknopolitan Pelalawan Area, to be elected persons with adequate communication, leadership, and entrepreneurial skills;

- Monitoring the way the organization, and actively provide solutions and mediators, in case of coordination deadlock between institutions, the private sector and the community.

- Socialization of the existence of Pelalawan Technological Area outside Pelalawan Regency, both within government institutions and business organizations;

Some concrete steps have been made by the Bupati Pelalawan, especially how to convince the central government of the importance of this great project for Pelalawan in particular and Indonesia in general. Persistence is what generates a positive signal from the center that promises to give maximum help to realize Teknopolitan in Langgam, Pelalawan.

Given the importance of Teknopolitan existence for Pelalawan in particular and Indonesia in general, Regent Pelalawan HM Harris considered very persistent to fight for the realization of development of Teknopolitan area in Langgam. Various efforts he did, starting with convincing all members of Parliament Pelalawan and all units in the ranks of Government Pelalawan District. They were given a presentation on what Tekhnopolitan was and what the Tekhnopolitan program was like. Also explained the benefits that can be obtained area with the Tekhnopolitan.

Furthermore, to offer and support Teknopolitan program support to Riau Provincial Government and central government. Because the policy of development of Teknopolitan area in Pelalawan Regency is basically a form of implementation or realization of efforts to accelerate and expand economic development as mandated in the President of the Republic of Indonesia number 32 of 2011 on Master Plan for the Acceleration and Expansion of Indonesia Economic Development (MP3EI) 2010-2025.

For that it is absolutely necessary a collaboration, but need to be realized in the collaboration can not only rely on commitment and capacity of one party only, there must be a shared commitment in a consensus to share resources to run the common goal of realizing technopolitan region in Pelalawan District.

\section{C) Collaborative Dynamics}

The third dimension of Collaborative Dynamics has three components that are illustrated in the development of technopolitan area in Pelalawan Regency, namely:

a. Principled Engagement, is a matter that arises over time between different stakeholders and parties in different settings.

b. Shared Motivation, emphasizes the elements that exist in aspects that are not visible in any personal, or seing is called social capital.

c. Capacity for Join action, with the collaboration it will benefit all parties in terms of resources, because it raises the potential for sharing and utilizing limited resources owned.

The emphasized dimension is the element of capacity for join action, because although explicitly the word Teknopolitan is not listed in the RPJMD, but what substance is the pillar or what will be built is the development target written in the Pelalawan District RPJMD.

However, considering the great benefits, the planned development of this technopolitan area was attacked by a number of ministries, among others, the Coordinating Minister for Economic Affairs of Indonesia which is also the Daily Chairman of the Committee for the Acceleration and Expansion of Indonesian Economic Development (KP3EI), Minister of State for Research and Technology RI and Head Agency for the Assessment and Application of Technology (BPPT) which has done the launching of Pelalawan Innovation Center on 10 April 2012 ago. The declaration that has been done by both Minister and Head of BPPT continued to be followed up by the officials of his subordinates, by coordinating the documents and preparing the technical policy.

One such follow up is currently in the process of submitting Pelalawan District to the Investment Concern area on the MP3EI system of the Economic Corridor of Sumatra. Even in 2012 out recommendation of the Ministry of Forestry for the regency of marine districts to be set investment attention area (KPI) with an indication of investment of 67 trillions. And now Pelalawan Regency has been determined to be one Area Investment Attention (KPI) in the Economic Corridor of Sumatra.

With the declaration of Pelalawan Regency as the area of investment concern (KPI), the policy of increasing and expanding economic development such as the development of techno-technological areas, the development of Bono tourism area, and even the planned development of special economic area in Sokoi village will be included in the MP3EI development system handled jointly between the central government and local governments by encouraging the entry of investment both from within and outside the country.

Many investment concern areas have been established in the Sumatera Corridor, however, realization of development 
and realization of the investment is different from one region to another. This is very dependent on the readiness of the region especially concerning the concept of development, the provision of land needed and more important is the willingness and determination of local governments in the success of MP3EI achievement.

The concept of Teknopolitan development that combines the increased value-added of palm oil products as the region's flagship commodity, supported by the continuous development of research and innovation as well as the development of higher education institutions as the provision of skilled workforce with a curriculum adapted to existing industries, in one region is the method of achievement new MP3EI vision.

The support of the central government, especially through the acceleration and expansion committees of economic development in Indonesia is very clear, the will and determination of Pelalawan district government has also been strong, therefore the moment and timeliness of realizing any planned phasing must be maintained. Loss of the moment may result in weak support, loss of stakeholder trust, and loss of opportunity and from center and slow implementation of targets.

\section{CONCLUSION}

The existence of Teknopolitan Pelalawan Region will ultimately be determined by the assessment of the stakeholders about the deliverables generated, whether it is able to provide added value more than the existing conditions. This condition will only happen if the management of Technopolitan Pelalawan Area is able to build strategic and synergic cooperation with related institution or organization in central and regional, both in technology and business.
Cooperation with central agencies should be directed to the utilization and transfer of production technologies capable of strengthening local resources in providing quality output and standards, as well as for organizational imaging. Meanwhile, coordination and collaboration with local agencies and partners is directed to a common focus on product development and marketing, strengthening of production resources, and raising a common working attitude to avoid institutional tangibles.

\section{REFERENCES}

[1] Hartman, C., et al. (2002). Environmental collaboration: potential and limits. In T. de Bruijn \& A. Tukker (Eds.), Partnership and Leadership: Building Alliances for a Sustainable Future (pp. 21-40). Dordrecht: Boston: Kluwer Academic Publishers. And, Cordery, J. (2004). Another case of the Emperor's new clothes? Journal of Occupational and Organizational Psychology, 77, 481-484

[2] Ansell dan Gash. 2007. Collaborative Governance in Theory and Practice, Journal of Public Adminsitration Research and Theory. Published by Oxford University Press. Hal. 544.

[3] Agrawal, Arun and Lemos, Maria Carmen, 2007. A Greener Revolution in The Making?. Enviromental Governance in the 21st Century. Vol. 49 Number 5 .

[4] Balogh, dkk. 2011. An Integrative Framework for Collaborative Governance, Journal of Public Administration Research and Theory 22: 1-29. (Halaman 3)

[5] Ibid. Balogh. Hal. 2

[6] Kumorotomo, Wahyudi, dkk. 2013. Transformasi Pelayanan Jakarta Commuter Line: Studi Tentang Collaborative Governance di Sektor Publik. Jurusan Manajemen dan Kebijakan Publik, FISIPOL UGM, Halaman. 10

[7] Dwiyanto, Agus. 2011. Manajemen Pelayanan Publik: Peduli, Inklusif, dan Kolaboratif. Yogyakarta. Gajah Mada University Press. Hal. 251

[8] Creswell, John W. 2015. "Research Desigin, Pendekatan Kualitatif, Kuantitatif, dan Mixed. Yogyakarta: Pustaka Pelajar. 